\title{
Restrictions recommended
}

\section{Tokyo}

AN advisory body to Japan's Ministry of Health and Welfare is expected to recommend restrictions this week on the use of the world's two top-selling anticancer drugs, Krestin and Picibanil.

The drugs are sold only in Japan and bring in hundreds of millions of dollars each year. But they have become the centre of controversy because of their questionable efficacy.

The Central Pharmaceutical Affairs Council is expected to rule that from now on the two drugs should be prescribed only in combination with other chemotherapeutic drugs and should not be prescribed alone. But a leading critic says the council's decision is unlikely to have much effect on prescription of the drugs and claims that there are serious defects in the process of drug re-evaluation which throw into question the council's impartiality.

Both drugs are so-called biological response modifiers - agents that change the body's response to tumour cells. Krestin is an extract of fungus and Picibanil is a penicillin-treated freeze-dried streptococcus. Both were put on the market in the mid-1970s and their combined sales rose rapidly to about $¥ 80,000$ million ( $\$ 570$ million) a year, which is an order of magnitude larger than sales of anti-cancer drugs in the United States, for example (see Commentary, page 850). Total sales so far amount to more than $¥ 1$ million

\section{ENVIRONMENT}

\section{Japan accepts ban on drift-net fishing}

\section{Tokyo}

UNDER international pressure, Japan last week agreed to stop using massive fishing nets to catch tuna and squid in the South Pacific Ocean, at least for the time being.

Japan, Taiwan and Korea have been severely criticized by South Pacific island nations, New Zealand, the United States and environmentalists for using drift nets up to $60 \mathrm{~km}$ in length in the Pacific Ocean (Nature 342, 9; 1989).

Last month, Japan and Taiwan refused to join an international ban on drift-net fishing in the Pacific (see Nature 342, 726; 1989). But Japan made a quick about-turn last week to avoid conflict with the United States.

The UN resolution endorsed by Japan last Friday calls for a ban from 1 July 1991 in the South Pacific and worldwide from 30 June 1992. But the ban can be waived if "effective conservation and management measures" are taken. And some environmentalists fear that this may provide Japan with a loophole. David Swinbanks million ( $\$ 7,000$ million).

Cancer experts have questioned the efficacy of Krestin and Picibanil for years and in 1987 the Ministry of Health and Welfare decided to re-evaluate them. Details of the council's recommendations had not been officially released when Nature went to press. But a ministry official confirms that recent reports in the Japanese press of the restrictions to be imposed are "more or less accurate".

Masanori Fukushima of Aichi Cancer Center, who has been campaigning to reform Japan's drug approval system, says the reported decision to allow these drugs to continue to be prescribed in combination with other chemotherapeutic agents represents a "gigantic loophole". The drugs are already usually prescribed in combination with other anti-cancer agents. And a spokesman for Kureha Industrial Company, which developed Krestin, has confirmed that Krestin is "nearly always" prescribed with other chemotherapeutic drugs.

Fukushima questions the ability of the the council's subcommitee on anti-cancer drugs to re-evaluate Krestin and Picibanil impartially. Fukushima points out that two of the seven subcommittee members carried out some of the clinical trials on Krestin which the subcommittee had to reassess. And a third member is on the editorial board of the journal Oncologia, which published their results. Furthermore, Oncologia was established and is financed by Kureha.

A Ministry of Health and Welfare official says that the overlap between members of the subcommittee and those that carried out clinical trials "cannot be helped" because the number of suitable experts in Japan is limited. He says that the root of the problem is the lack of government finance for medical research. He points out that the ministry, which finances the larger part of Japan's medical research, has a budget of only about $¥ 50,000$ million ( $\$ 350$ million) per year, less than one tenth that of the US National Institutes of Health. And so "inevitably" Japanese medical researchers have to seek the financial support of pharmaceutical companies by carrying out clinical trials.

$\mathrm{He}$ says that almost all Japanese pharmaceutical companies have their own in-house journals for quick publication of clinical trial results. And while sympathizing with Fukushima's proposal that all clinical trial results used in drug assessment should be published in English in international journals he says this is impractical because of the time it takes.

But Fukushima says that there are plenty of internationally known Japanese researchers capable of carrying out assessment of clinical trials. David Swinbanks

\section{Selling student places}

London

THE heads of UK universities last week received details of a new system of competitive bidding for undergraduate places in a letter from the Universities Funding Council (UFC). By June 1990, each university will have to say how many undergraduate places it wishes to make available in each subject area by the 1994-95 academic year, and make an 'offer price' per student for each subject.

Guide prices will be issued within the next few weeks, but the letter notes that "in some (if not all) subjects, universities may wish to ... improve their chances of having their offers accepted in full by quoting a price below the guide price". Where lower offer prices are made, UFC will leave it to individual universities to show that "adequate arrangements exist for assessing . . academic standards".

After assessing the bids, UFC will inform each university by early 1991 of the number of student places to be supported and the prices for teaching that have been accepted for the 1991-92 academic year, together with provisional figures for the three following years. As well as cost and teaching quality, the UFC says the range of subject provision and the balance between different subjects will be taken into account in the allocation of student places and teaching grants to the universities.

Some subject areas are excluded from the competitive bidding system. Student numbers for medicine, dentistry and veterinary science will be allocated to universities by the UFC and supported at the relevant guide price.

The new system reflects the government's desire for a more market-orientated university system. Sir Peter SwinnertonDyer, chief executive of UFC, says that the new arrangements will "increase institutional autonomy and widen student choice as the balance of public funding for higher education moves from centrally provided grants to fees".

The government expects student numbers to increase by just under 10 per cent between 1988-89 and 1992-93, and for there to be a shift towards science and technology. UFC expects an increase of at least 10 per cent by 1994-95 but the exact figure will depend on the universities' bids.

The Committee of Vice-Chancellors and Principals (CVCP) was concerned at its meeting last Friday that funding for the universities for 1990-91 may not be sufficient to provide "satisfactory pay settlements". It has also announced the formation of an 'Academic Audit Unit' to review each university's mechanisms for monitoring academic standards. A full statement on the competitive bidding system is now epected in mid-January, after the next CVCP meeting.

Peter Aldhous 